\title{
Situs inversus
}

\section{Situs inversus}

\section{Luciana Luna-Abanto ${ }^{1}$, Jorge Luna-Abanto ${ }^{2,3}$}

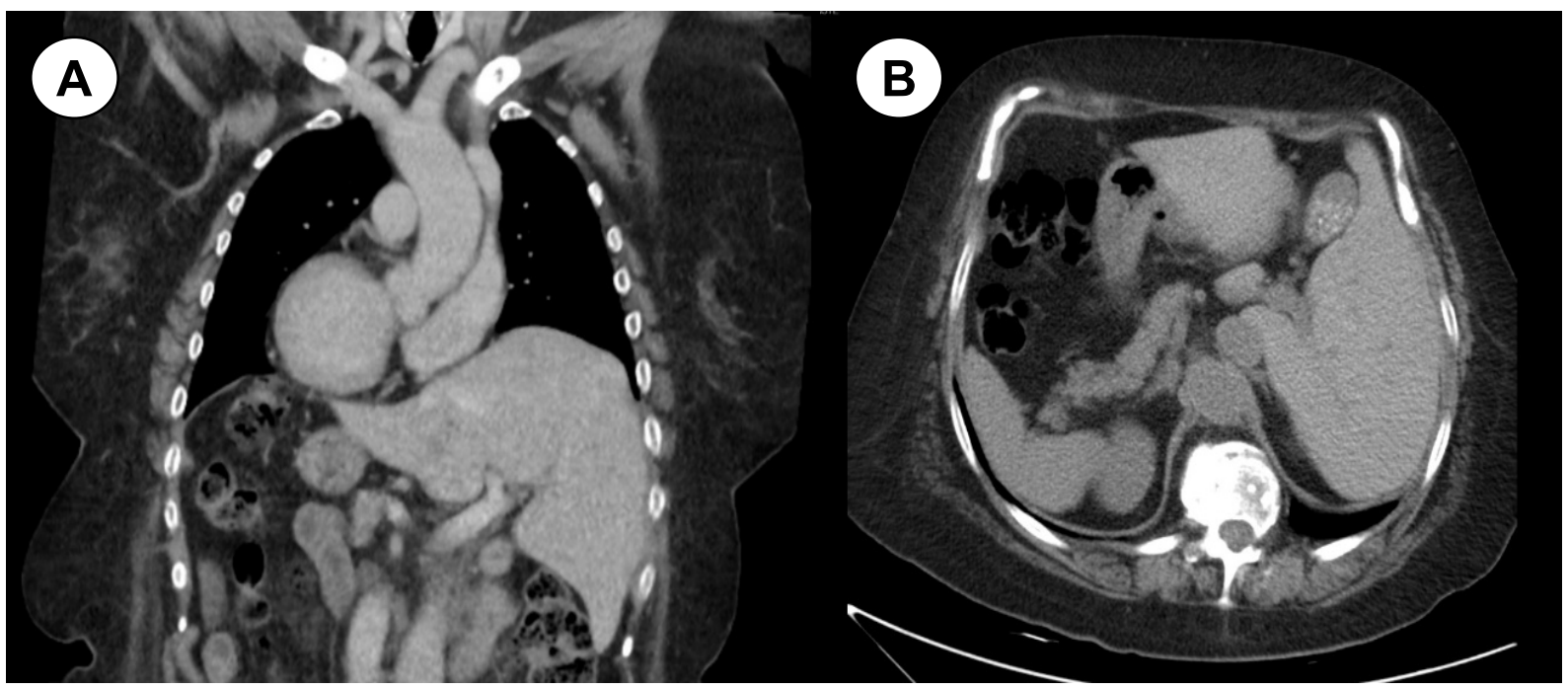

Mujer de 39 años con diagnóstico de cáncer epidermoide de cuero cabelludo, clínicamente asintomática. En el contexto de estadiaje de la enfermedad de fondo se solicitó tomografía de tórax y abdomen. El corte coronal (A) mostró dextrocardia e hígado ubicado en hipocondrio izquierdo, no visualizándose la porción intrahepática de la vena cava inferior. En el corte axial (B), se observó hígado en hipocondrio izquierdo y bazo, cámara gástrica y páncreas de localización derecha. Bazo accesorio en hilio esplénico, que mide $15 \mathrm{~mm}$. Estos hallazgos corresponden a situs inversus, una variante de la normalidad

A 39-year-old female patient who presented with the diagnosis of epidermal cancer of the scalp but was otherwise asymptomatic. While being study for the extension of disease a CT scan of the chest and abdomen revealed a dextrocardia and showed that the liver was located on the left side of the abdomen, not observing the intrahepatic portion of the a inferior vena cava. In the axial view the liver was found on the left hypochondrium and the spleen, stomach and pancreas were located on the right side, an accessory spleen was found in the splenic hilum. These findings are compatible with situs inversus, a variant of normality.

\section{Correspondencia:}

Jorge Luna-Abanto

Dirección: Avenida Angamos Este 2520 Surquillo Lima, Perú.

Teléfono: 012016500

Correo electrónico: Jorgelunaabanto@gmail.com

\footnotetext{
Escuela profesional de Medicina Humana, Universidad Privada Antenor Orrego. Trujillo, Perú.

Departamento de Cirugía Oncológica, Instituto Nacional de Enfermedades Neoplásicas. Lima, Perú.

Escuela de Posgrado, Universidad Peruana Cayetano Heredia. Lima, Perú.
} 